\title{
Magic Mushrooms: Screening for Novel Biocatalysts in the Phylum Basidiomycota
}

\author{
Christoph Loderer, Marion B. Ansorge-Schumacher* \\ Technische Universität Dresden, Dresden, Germany \\ Email: *marion.ansorge@tu-dresden.de
}

How to cite this paper: Loderer, C. and Ansorge-Schumacher, M.B. (2016) Magic Mushrooms: Screening for Novel Biocatalysts in the Phylum Basidiomycota. Advances in Bioscience and Biotechnology, 7, 446-453. http://dx.doi.org/10.4236/abb.2016.711043

Received: October 6, 2016

Accepted: November 8, 2016

Published: November 11, 2016

Copyright $\odot 2016$ by authors and Scientific Research Publishing Inc. This work is licensed under the Creative Commons Attribution International License (CC BY 4.0).

http://creativecommons.org/licenses/by/4.0/

\begin{abstract}
The ascending application of enzymes in organic synthesis creates a growing demand for novel biocatalysts. The applied methods for their identification range from microbial enrichment cultures over metagenome screenings to solely computational methods. In this communication, we demonstrate a straightforward screening approach for the detection of novel biocatalysts in fungi belonging to the phylum Basidiomycota. It basically relies on mincing of the whole fruit bodies of freshly collected mushrooms with subsequent direct screening. Suitability was demonstrated with eight different mushrooms which were investigated for carbonyl reductase activity on sterically demanding carbonyl compounds. The results indicate the presence of potentially useful carbonyl reductases (KREDs) in all tested fungi. Closer characterization of the preparation from pigskin poison puffball (Scleroderma citrinum) showed the presence of KRED exhibiting a broad substrate range. Thus, applicability of this low-tech screening approach could be verified in this study.
\end{abstract}

\section{Keywords}

Biocatalysis, Carbonyl Reduction, Screening, Biological Source

\section{Introduction}

Enzymes are an increasingly important tool for the synthesis of commodity as well as fine chemicals, applications ranging from lab to industrial scale [1] [2]. Thus the identification of novel enzymes with new characteristics and functionalities is required to meet the ever-changing/evolving requirements for the growing number of processes. Strategies for this task are numerous [3]. A classical approach is the utilization of enrichment cultures, where a biological sample is treated with a potential substrate. Microorganisms with an ability to metabolize the given substrate are enriched and may then be used as a source for enzymes modifying the given compound [4]. Another 
prominent approach is the screening of organism or metagenome libraries for a desired enzyme activity [5]. All these strategies have in common that they mainly focus on microbial targets. In general, this is reasonable since bacteria, archaea and simple eukaryotic organisms provide a large part of the metabolic variety in the biosphere. Nevertheless, a part of this variety is neglected, since large eukaryotic organisms cannot easily be included in the screening procedures. For instance, fungi of the phylum of Basidiomycota are known to synthesize various complex compounds, some of pharmaceutical interest, within their secondary metabolism [6]. This requires an expanded set of enzymes to specifically catalyze the corresponding reactions. A prominent example is the fungal lignin degradation, performed by specific laccases and peroxidases [7] [8]. These metabolic abilities render Basidiomycota a promising source for novel biocatalysts.

An example for a successful Basiodiomycota derived biocatalyst is the laccase from Trametes versicolor [9]. Its presence could be demonstrated in vivo and in vitro by Evans [10]. Later the responsible enzyme was isolated [11] and has since been applied in various biotechnological and industrial applications such as dye decolorization, degradation of xenobiotics or Denim bleaching [12]. A screening for novel laccases in basidiomycetes was successfully conducted applying cell cultures as starting material [13].

Considering the difficulty in the cultivation of fungi and their high potential as source for biocatalysts for biotechnological applications a culture independent screening procedure for a specific enzyme activity in Basidiomycota would be useful.

In this study, we demonstrate a screening approach for enzyme activity based on the direct application of minced fruit bodies of freshly collected mushrooms from the phylum Basidiomycota. Simple as it is, this has to our knowledge never been described before. Sample candidates were screened for carbonyl reductase (KRED) activity on sterically demanding substrates. The chiral alcohols resulting from their reaction are relevant as chemical building blocks and precursors for pharmaceuticals [14] [15]. The extract from the most promising candidate, the pigskin poison puffball (Scleroderma citrinum, Figure 1), was characterized in detail.

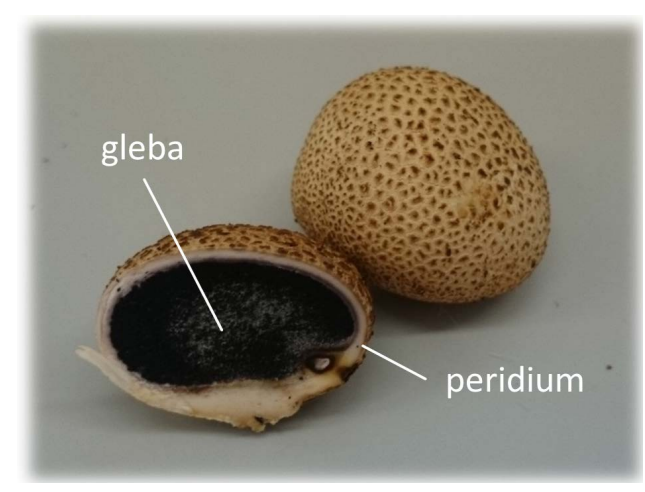

Figure 1. Pigskin poison puffball (Scleroderma citrinum) with gleba and peridium. 


\section{Materials and Methods}

\subsection{Provision of Biological Material}

Mushrooms for the screening were collected at Dresdner Heide $\left(51^{\circ} 04^{\prime} 12.0^{\prime \prime} \mathrm{N}\right.$, $13^{\circ} 51^{\prime} 36.0^{\prime E}$ ) on the 12.10.2014. Fruit bodies from the species Clitocybe nebularis, Entoloma undatum, Lactarius deterrimus, Laccaria amethystina, Amanatia muscarina, Boletus badius, Suillus bovinus and Scleroderma citrinum were collected. Mushrooms were identified by phenotypical traits according to fungal determination literature [16] [17]. For detailed characterization of Scleroderma citrinum a second batch was collected on 24.10.2014 at the same location. In case of all candidates except for Scleroderma citrinum, complete fruit bodies without mycelium were cleaned by rinsing in water and minced for $30 \mathrm{sec}$ with a Braun 160 Watt hand blender. The minced material was directly applied in the activity assays. For Scleroderma citrinum the tough outer wall (peridium) was removed leaving the soft gleba, which was minced and applied (Figure 1).

\subsection{Activity Assay}

Activity was measured in $100 \mathrm{mmol} \cdot \mathrm{L}^{-1}$ triethanolamin (TEA) buffer containing 3 $\mathrm{mmol} \cdot \mathrm{L}^{-1}$ substrate, $250 \mu \mathrm{mol} \cdot \mathrm{L}^{-1} \mathrm{NADH}$ and $5 \%(\mathrm{v} / \mathrm{v})$ isopropyl alcohol in $500 \mu \mathrm{L}$ scale as described previously [18]. Reactions were started by addition of $100 \mathrm{mg}$ minced mushroom preparation and performed at $25^{\circ} \mathrm{C}$ and $700 \mathrm{RPM}$ for $22 \mathrm{~h}$. Conversion and yield of each reaction was determined via chiral GC. For determination of the $\mathrm{pH}$ profile, acetate buffer ( $\mathrm{pH} 5.0)$, phosphate buffer $(\mathrm{pH} \mathrm{5.0,6.0)}$ and TEA buffer ( $\mathrm{pH} 7.0$, 8.0, 9.0) were applied. The $\mathrm{pH}$ - and temperature profiles were measured with benzaldehyde as substrate. All assays except for the initial screening were performed in triplicates and the standard deviations are given as error bars in the figures.

\subsection{Analytics}

Determination of substrate and product concentrations was conducted by chiral GC analysis. The quantification of all compounds was performed on a Shimadzu GC2010 gas chromatography system with FID detection system and a Hydrodex $\gamma$ DIMOM column. In all methods a sample volume of $2 \mu \mathrm{L}$ was injected with a split ratio of 20 . Nitrogen was applied as carrier gas for all measurements. For aromatic substrates the separation was conducted at $130^{\circ} \mathrm{C}$ for $12 \mathrm{~min}$. For [C5]-compounds a linear temperature gradient from $95^{\circ} \mathrm{C}$ to $115^{\circ} \mathrm{C}$ over 13 min was applied. For [C6]-compounds a linear temperature gradient from $98^{\circ} \mathrm{C}$ to $122^{\circ} \mathrm{C}$ over 12 min was applied.

\section{Results and Discussion}

\subsection{Carbonyl Reductase Activity Screening}

Eight different mushrooms from the phylum Basidiomycota were screened for carbonyl reductase activity. As substrates, the aromatic ketone acetophenone and the aliphatic diketone 3,4-hexanedione were tested. Figure 2 shows the reaction yields achieved after $22 \mathrm{~h}$ reaction time. All tested preparations exhibited carbonyl reductase activity on 


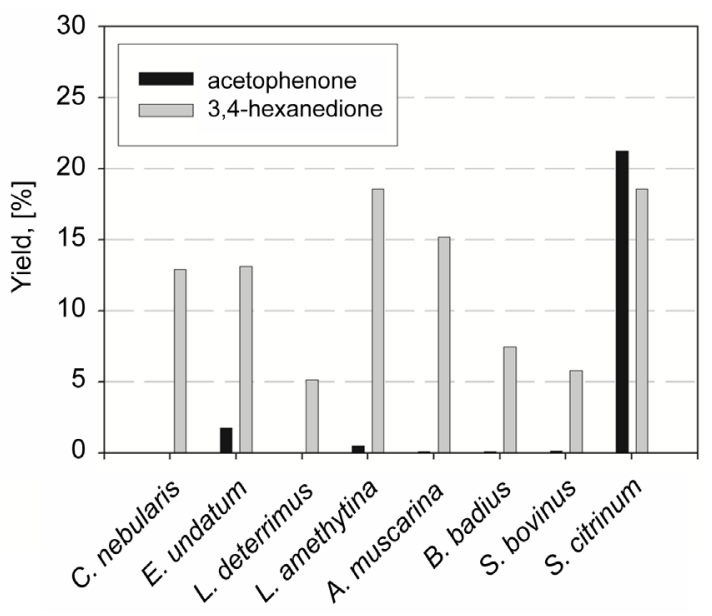

Figure 2. Conversions for the reduction of acetophenone and 3,4-hexanedione by various Basidiomycota preparations. Reactions were conducted for $22 \mathrm{~h}$ at $25^{\circ} \mathrm{C}$ and a $\mathrm{pH}$-value of 7.0.

3,4-hexanedione with yields ranging between 5 and 20\%, which demonstrates the suitability of the screening procedure to render enzymes active. The preparations from Entoloma undatum, Laccaria amethystine and Scleroderma citrinum also exhibited significant activity on acetophenone as substrate, yielding 0.5 to $21 \%$ 1-phenyl ethanol. All three preparations showed $(S)$-selectivity with no detectable enantiomeric impurity. With conversions of $18.6 \%$ in the 3,4-hexanedione reduction and $21.2 \%$ in the acetophenone reduction, Scleroderma citrinum was the most promising candidate of this screening. Thus, a more detailed characterization of this preparation was conducted.

\subsection{KRED-Activity of Scleroderma citrinum}

The substrate specificity of the Scleroderma citrinum preparation was further characterized by determination of conversion and reaction yield for five carbonyl substrates, applying a preparation from a second batch of the mushroom. The reductions of ethyl pyruvate and 2,3-pentanedione yielded 3 to $5 \%$ of the corresponding hydroxy ketones. Benzaldehyde and 3,4-hexanedione reduction exhibited the highest yields with 16\% each (Figure 3). The reduction of acetophenone yielded $0.2 \% 1$-phenylethanol. This is noteworthy, since the first preparation from Scleroderma citrinum showed equally high yields for the reduction of acetophenone and 3,4-hexanedione, whereas the second preparation showed significantly higher yields for the latter substrate. Since the mushroom preparations are biological samples, collected at a specific sampling time, the expression level of a certain protein may vary significantly. These variations may be caused by environmental influences such as humidity or temperature and by physiological influences such as the age of the specific mushroom and its stage of development [19]. In summary, the Scleroderma citrinum preparation showed carbonyl reductase activity on all tested substrates and the results from the screening could be confirmed by trend. Stereoselectivity was investigated for the reduction of acetophenone and 2,3-pentanedione, showing clear $(S)$-selectivity for both substrates. 


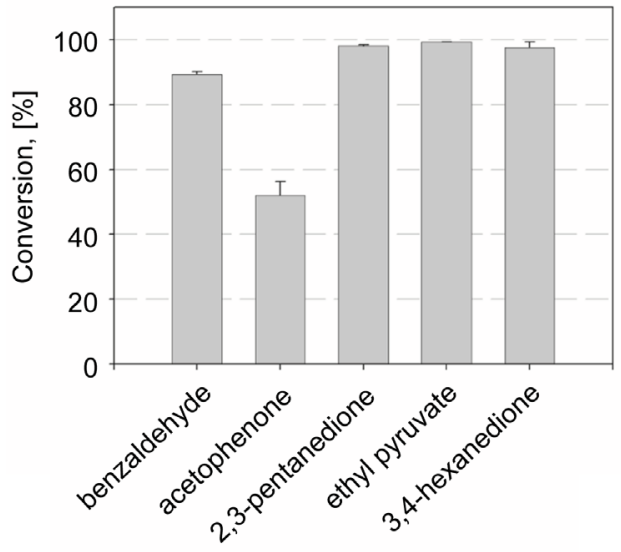

(a)

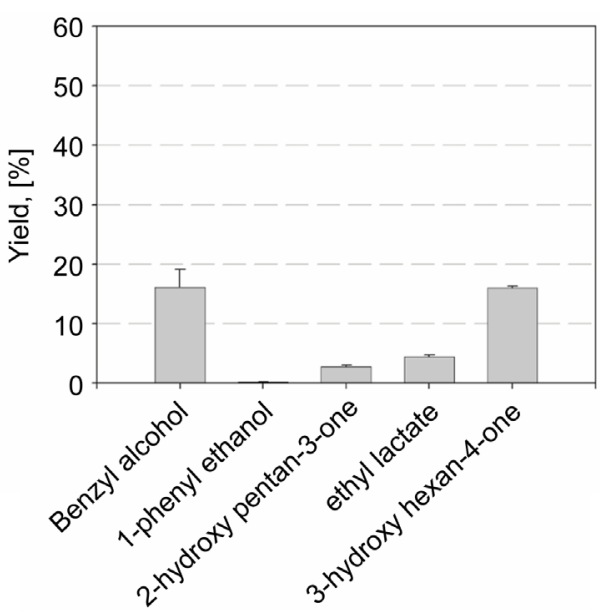

(b)

Figure 3. (a) Conversion and (b) yield of carbonyl compounds by Scleroderma citrinum. Reactions were conducted for $22 \mathrm{~h}$ at $25^{\circ} \mathrm{C}$ and a value $\mathrm{pH}$ of 7.0.

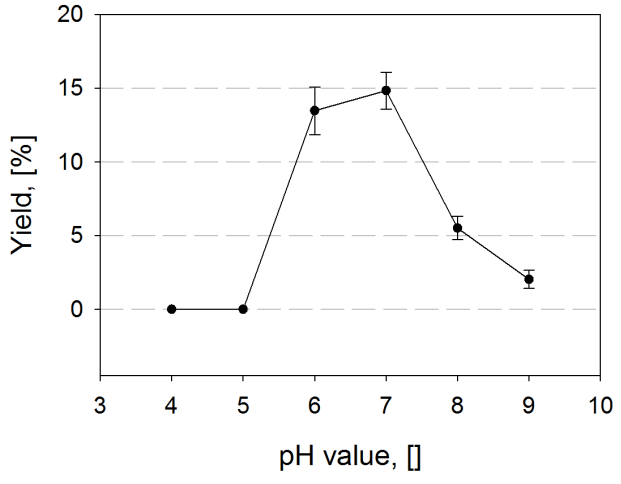

(a)

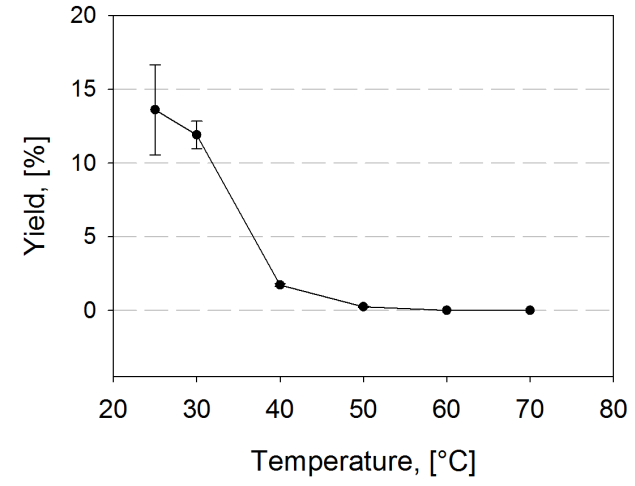

(b)

Figure 4. (a) $\mathrm{pH}$ - and (b) temperature profile of the Scleroderma citrinum catalyzed reduction of benzaldehyde. Reactions were conducted for $22 \mathrm{~h}$ at $25^{\circ} \mathrm{C}(\mathrm{pH}$-profile) and a $\mathrm{pH}$-value of 7.0 (temperature profile), respectively.

It is noteworthy, that the conversions were very high for all substrates ranging between 50 and 99\% (Figure 3). Thus the largest part of the deployed substrate was converted without ending up as reaction product after $22 \mathrm{~h}$. Since the preparations were minced gently it is likely that cells of the mushroom and here especially the spores were still intact to a certain degree. Thus, the consumption of the substrate may be interpreted as a metabolization of the compound by viable cells or a further degradation by released enzymes. The best example here is ethyl pyruvate, where $99 \%$ of the substrate was consumed, while only $4.4 \%$ of the reaction product ethyl lactate was yielded. Thus, 95\% of the deployed substrate was converted otherwise. Depending on the target of the screening this effect has certainly to be taken into account.

The $\mathrm{pH}$ profile of the preparations shows maximum activity in a range between $\mathrm{pH}$ 6.0 and 7.0 (Figure 4). At higher $\mathrm{pH}$ values activity decreases to a residual yield of $14 \%$ compared to $\mathrm{pH} 7.0$, while at lower $\mathrm{pH}$ values no product could be detected. The tem- 
perature profile shows highest Yield at temperatures of up to $30^{\circ} \mathrm{C}$. At $40^{\circ} \mathrm{C}$ the yield is reduced to $13 \%$ of the maximal value. Over $50^{\circ} \mathrm{C}$ no product formation could be detected (Figure 4).

The characterization indicates that the preparation of Scleroderma citrinum contains at least one active carbonyl reductase. At this stage, of course, it is not clear if the described characteristics can be attributed to a single enzyme or if they are the merged characteristics of two or more enzymes. The likeability of the latter has for example been demonstrated for the carbonyl reductase activity of Candida parapsilosis described by Kula and coworkers in 1995 [20]. Only in 2011 it became clear, that the CPCR preparation actually contained two enzymes where one is mainly responsible for the characteristics that were initially described [21].

\section{Conclusion}

In this study, we demonstrate that crude mincing of freshly collected mushrooms is a viable screening approach to obtain valuable novel enzymes from Basidiomycota. Mining for NADH-dependent carbonyl reductases gave activity in all tested preparations with most promising results in the pigskin poison puffball (Scleroderma citrinum). In an appropriate season and location sufficient amounts for sampling can easily be collected. Despite natural sample related reproducibility issues, this screening approach is a useful low tech strategy for the detection of novel biocatalysts from higher fungi with potential for a high throughput method. Thus, it can help expanding the scope of available enzymes for biosynthetic use.

\section{Acknowledgements}

Deutsche Forschungsgemeinschaft (DFG) is greatly acknowledged for financial support within the research project AN 387/4-1 and within the collaborative research network BioNoCo (GRK1166).

\section{References}

[1] Bornscheuer, U.T., Huisman, G.W., Kazlauskas, R.J., Lutz, S., Moore, J.C. and Robins, K. (2012) Engineering the Third Wave of Biocatalysis. Nature, 485, 185-194. http://dx.doi.org/10.1038/nature11117

[2] Sanchez, S. and Demain, A.L. (2011) Enzymes and Bioconversions of Industrial, Pharmaceutical, and Biotechnological Significance. Organic Process Research \& Development, 15, 224-230. http://dx.doi.org/10.1021/op100302x

[3] Ni, Y. and Xu, J.H. (2012) Biocatalytic Ketone Reduction: A Green and Efficient Access to Enantiopure Alcohols. Biotechnology Advances, 30, 1279-1288. http://dx.doi.org/10.1016/j.biotechadv.2011.10.007

[4] Gabor, E.M., de Vries, E.J. and Janssen, D.B. (2004) Construction, Characterization, and Use of Small-Insert Gene Banks of DNA Isolated from Soil and Enrichment Cultures for the Recovery of Novel Amidases. Environmental Microbiology, 6, 948-958. http://dx.doi.org/10.1111/j.1462-2920.2004.00643.x

[5] Voget, S., Leggewie, C., Uesbeck, A., Raasch, C., Jaeger, K.E. and Streit, W.R. (2003) Prospecting for Novel Biocatalysts in a Soil Metagenome. Applied and Environmental Microbi- 
ology, 69, 6235-6242. http://dx.doi.org/10.1128/AEM.69.10.6235-6242.2003

[6] Wasser, P. and Weis, L. (1999) Medicinal Properties of Substances Occurring in Higher Basidiomycetes Mushrooms: Current Perspectives. International Journal of Medicinal $\mathrm{Mu}$ shrooms, 1, 31-62. http://dx.doi.org/10.1615/IntJMedMushrooms.v1.i1.30

[7] Buttner, E., Ullrich, R., Strittmatter, E., Piontek, K., Plattner, D.A., Hofrichter, M. and Liers, C. (2015) Oxidation and Nitration of Mononitrophenols by a DyP-Type Peroxidase. Archives of Biochemistry and Biophysics, 574, 86-92. http://dx.doi.org/10.1016/j.abb.2015.03.003

[8] Dashtban, M., Schraft, H., Syed, T.A. and Qin, W. (2010) Fungal Biodegradation and Enzymatic Modification of Lignin. International Journal of Biochemistry and Molecular Biology, 1, 36-50.

[9] Bertrand, T., Jolivalt, C., Briozzo, P., Caminade, E., Joly, N., Madzak, C. and Mougin, C. (2002) Crystal Structure of a Four-Copper Laccase Complexed with an Arylamine: Insights into Substrate Recognition and Correlation with Kinetics. Biochemistry, 41, 7325-7333. http://dx.doi.org/10.1021/bi0201318

[10] Evans, C.S. (1985) Laccase Activity in Lignin Degradation by Coriolus versicolor in Vivo and in Vitro Studies. FEMS Microbiology Letters, 27, 339-343. http://dx.doi.org/10.1111/j.1574-6968.1985.tb00693.x

[11] Ullah, M.A., Bedford, C.T. and Evans, C.S. (2000) Reactions of Pentachlorophenol with Laccase from Coriolus versicolor. Applied Microbiology and Biotechnology, 53, 230-234. http://dx.doi.org/10.1007/s002530050013

[12] Couto, R.S. and Herrera, T.J.L. (2006) Industrial and Biotechnological Applications of Laccases: A Review. Biotechnology Advances, 24, 500-513. http://dx.doi.org/10.1016/j.biotechadv.2006.04.003

[13] Peláez, F., Martínez, M.J. and Martínez, A.T. (1995) Screening of 68 Species of Basidiomycetes for Enzymes Involved in Lignin Degradation. Mycological Research, 99, 37-42. http://dx.doi.org/10.1016/S0953-7562(09)80313-4

[14] Breuer, M., Ditrich, K., Habicher, T., Hauer, B., Keßeler, M., Stürmer, R. and Zelinski, T. (2004) Industrielle Verfahren zur Herstellung von optisch aktiven Zwischenprodukten. Angewandte Chemie, 116, 806-843. http://dx.doi.org/10.1002/ange.200300599

[15] Hoyos, P., Sinisterra, J.V., Molinari, F., Alcántara, A.R. and Domínguez de María, P. (2009) Biocatalytic Strategies for the Asymmetric Synthesis of Alpha-Hydroxy Ketones. Accounts of Chemical Research, 43, 288-299. http://dx.doi.org/10.1021/ar900196n

[16] Rathbone, A. (2005) Das große Buch der Pilze. Parragon Köln, Köln.

[17] Laux, H.E. (2014) Eßbare pilze und ihre giftigen Doppelgänger. Franckh-Kosmos, Stuttgard.

[18] Loderer, C., Dhoke, G.V., Davari, M.D., Kroutil, W., Schwaneberg, U., Bocola, M. and Ansorge-Schumacher, M.B. (2015) Investigation of Structural Determinants for the Substrate Specificity in the Zinc-Dependent Alcohol Dehydrogenase CPCR2 from Candida parapsilosis. Chembiochem, 16, 1512-1519. http://dx.doi.org/10.1002/cbic.201500100

[19] Park, Y.J., Baek, J.H., Lee, S., Kim, C., Rhee, H., Kim, H., Seo, J.S., Park, H.R., Yoon, D.E., Nam, J.Y., Kim, H.I., Kim, J.G., Yoon, H., Kang, H.W., Cho, J.Y., Song, E.S., Sung, G.H., Yoo, Y.B., Lee, C.S., Lee, B.M. and Kong, W.S. (2014) Whole Genome and Global Gene Expression Analyses of the Model Mushroom Flammulina velutipes Reveal a High Capacity for Lignocellulose Degradation. PLoS ONE, 9, e93560.

http://dx.doi.org/10.1371/journal.pone.0093560

[20] Peters, J., Minuth, T. and Kula, M.R. (1993) A Novel NADH-Dependent Carbonyl Reduc- 
tase with an Extremely Broad Substrate Range from Candida parapsilosis. Purification and Characterization. Enzyme and Microbial Technology, 15, 950-958.

http://dx.doi.org/10.1016/0141-0229(93)90171-W

[21] Jakoblinnert, A., Bocola, M., Bhattacharjee, M., Steinsiek, S., Bonitz-Dulat, M., Schwaneberg, U. and Ansorge-Schumacher, M.B. (2012) Who's Who? Allocation of Carbonyl Reductase Isoenzymes from Candida parapsilosis by Combining Bio- and Computational Chemistry. Chembiochem, 13, 803-809. http://dx.doi.org/10.1002/cbic.201200023

Submit or recommend next manuscript to SCIRP and we will provide best service for you:

Accepting pre-submission inquiries through Email, Facebook, LinkedIn, Twitter, etc.

A wide selection of journals (inclusive of 9 subjects, more than 200 journals)

Providing 24-hour high-quality service

User-friendly online submission system

Fair and swift peer-review system

Efficient typesetting and proofreading procedure

Display of the result of downloads and visits, as well as the number of cited articles

Maximum dissemination of your research work

Submit your manuscript at: http://papersubmission.scirp.org/

Or contact abb@scirp.org 